\title{
Teaching Video NeuroImages: A 20-year-old man with distal paresthesia
}

Amanda Stafford, MB, ChB, and Chinar Osman, MB, BS

Neurology ${ }^{\circledR}$ 2019;92:e170. doi:10.1212/WNL.0000000000006728

Figure MRI sagittal T2

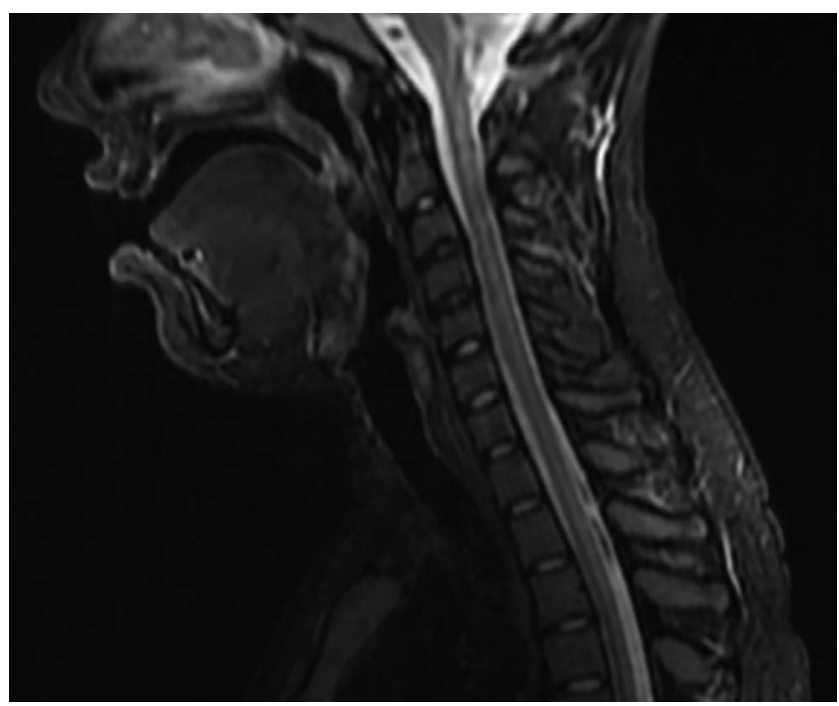

A 20-year-old man presented with a 3-week history of progressive distal paresthesia in his lower limbs. His gait became clumsy and he became unable to mobilize. The patient was vegetarian and after questioning admitted to regular recreational nitrous oxide use.

Examination revealed a clear dorsal column syndrome with pseudoathetosis of the upper limbs and reduced proprioception of upper and lower limbs with reduced vibration sensation to the xiphisternum. Knee jerk reflexes were brisk bilaterally with absent ankle jerk reflexes and extensor plantars (figure, video 1).

MRI showed high signal in the dorsal column throughout the spinal cord. Vitamin $\mathrm{B}_{12}$ levels were low $(84 \mathrm{ng} / \mathrm{L})$. This presentation represents subacute combined degeneration of the cord secondary to nitrous oxide abuse by inactivating $B_{12}$ levels. The patient was treated with vitamin $\mathrm{B}_{12}$ replacement and intensive neurorehabilitation. Nitrous oxide abuse should always be considered in a young patient with dorsal column syndrome. ${ }^{1}$

\section{Study funding}

No targeted funding reported.

\section{Disclosure}

The authors report no disclosures relevant to the manuscript. Go to Neurology.org/N for full disclosures.

\section{Reference}

1. Vasconcelos OM, Poehm EH, McCarter RJ, Campbell WW, Quezado ZM. Potential outcome factors in subacute combined degeneration review of observational studies. J Gen Intern Med 2006;21:1063-1068.

\section{Correspondence}

Dr. Stafford

a.stafford@doctors.org.uk

\section{MORE ONLINE}

\section{- Video}

$\rightarrow$ Teaching slides

links.lww.com/WNL/

A771

From Wessex Neurological Centre, University Hospital Southampton NHS Foundation Trust, UK. 


\title{
Neurology
}

\author{
Teaching Video NeuroImages: A 20-year-old man with distal paresthesia \\ Amanda Stafford and Chinar Osman \\ Neurology 2019;92; 170 \\ DOI 10.1212/WNL.0000000000006728
}

This information is current as of January 7, 2019

\section{Updated Information \& Services}

\section{References}

Subspecialty Collections

Permissions \& Licensing

Reprints including high resolution figures, can be found at: http://n.neurology.org/content/92/2/e170.full

This article cites 1 articles, 0 of which you can access for free at: http://n.neurology.org/content/92/2/e170.full\#ref-list-1

This article, along with others on similar topics, appears in the following collection(s):

All Medical/Systemic disease

http://n.neurology.org/cgi/collection/all_medical_systemic_disease All Spinal Cord

http://n.neurology.org/cgi/collection/all_spinal_cord

Clinical neurology examination

http://n.neurology.org/cgi/collection/clinical_neurology_examination Other toxicology

http://n.neurology.org/cgi/collection/other_toxicology

Information about reproducing this article in parts (figures,tables) or in its entirety can be found online at:

http://www.neurology.org/about/about_the_journal\#permissions

Information about ordering reprints can be found online:

http://n.neurology.org/subscribers/advertise

Neurology ${ }^{\circledR}$ is the official journal of the American Academy of Neurology. Published continuously since 1951 , it is now a weekly with 48 issues per year. Copyright @ 2019 American Academy of Neurology. All rights reserved. Print ISSN: 0028-3878. Online ISSN: 1526-632X.

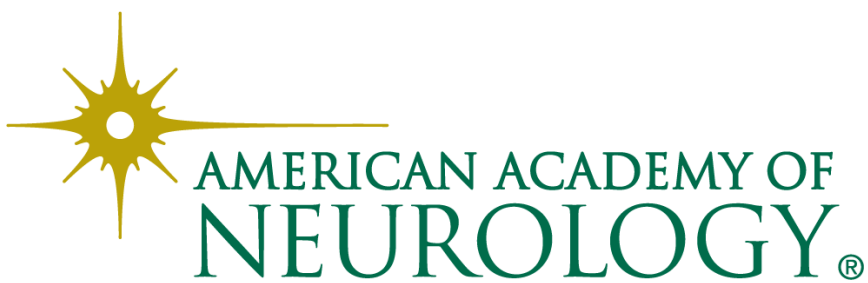

